\title{
SANAT PRATIKLERINDE PORTRE DENEMELERI
}

\author{
Öğr. Gör. Dr. Ahmet UZUNER*
}

Öz: Bu çalışmada portre konusunun yüzyıllardır sanatın en önemli konularından biri olması sebebiyle bu olgunun sosyolojik, felsefik, psikolojik, ekonomik, kültürel vb. kavramlar üzerinden incelenmesi amaçlanmıştır. Günümüzde sanat, kendisine ait alanların yanında diğer farklı alanlarında içine katıldığı disiplinler arası bir yapı olarak öne çıkmaktadır. Bu disiplinler arasılık sanatçılara farklı tekniklerde eser üretmelerine olanak sağladığı görülmektedir. Sanatçılarda günümüz sanatı içinde portre, natürmort, manzara...gibi konuları farklı sanatsal alanlar ile psikoloji, sosyoloji, edebiyat,....gibi alanları içine katarak yapıtlarını oluşturdukları görülmektedir. Yapıtlarda bilgisayar programları, resim, heykel, grafik gibi farklı sanatsal alanların yanında kolaj, asamblaj, rölyef ve üç boyutlu nesne gibi farklı teknik ve malzemenin kullanılmasıyla değişik özelliklere sahip portre görüntüleri elde edilmiştir. Portre yapıtları sanatsal alanlarla birlikte psikoloji, sosyoloji, edebiyat, antropoloji.....gibi farklı alanların etkisiyle zenginleştirilmektedir. Bunun yanında bu kavramlarla iletişime geçerek teknik, biçimsel ve içeriksel yönden değişimler geçirdiği yapılan araştırmalar sonucunda anlaşılmıştır.

Anahtar Kelimeler: portre, çağdaş sanat, disiplinler arasılık, çoğulculuk.

\section{PORTRAIT ESSAYS IN THE ARTISTIC PRACTICES*}

Abstract: As the portraiture has been one of the most significant artistic subjects for centuries, this study is intended to analyze this phenomenon in terms of sociological, philosophical, economical, cultural and other concepts. Today art has been featured as an interdisciplinary structure covering the different fields as well as its own fields. This interdisciplinarity is seen to allow the artists to produces their works in different techniques. Today's artists have created their works on the subjects like portrait, nature mort and landscape by merging different artistic fields with the fields like psychology, sociology and literature. The subject was discussed with its corporate structure in the section of practices herein and the findings from the thesis are tried to be synthesized in harmony and turned into the works. Portrait images with different characteristics were produced by using the different techniques and materials like collage, assemblage, relief and three dimensional objects as well as the different artistic fields like software programs, painting, sculpture and graphics. It follows from the researchers conducted that works are enriched with the effect of artistic fields of the portrait as well as the different fields like psychology, sociology, literature and anthropology and that they are transformed technically, formalistically and contextually in interaction with the abovementioned concepts.

Key Words: portrait, contemporary art, interdiciplinarity, pluralism.

$\begin{array}{ll}\text { ORCID ID } & : \text { 0000-0003-4509-9844 } \\ \text { DOI } & : 10.31126 / \text { akrajournal.808907 } \\ \text { Geliș tarihi } & : 11 \text { Ekim 2020 / Kabul tarihi: } 15 \text { Aralık 2020 } \\ \text { *Kahramanmaraş Sütçü İmam Üniversitesi Güzel Sanatlar Bölümü. }\end{array}$


Öğr. Gör. Dr. AHMET UZUNER

\section{Giriş}

Portre yüzyıllardır resim sanatının en önemli konularından biri olarak süregelmiştir. Geçen yüzyıllar içinde portrenin biçim ve anlamı; coğrafyaya, sosyo-ekonomik duruma, psikolojiye, dine ve politikaya göre değişiklik göstermiştir. Bu değişimin en belirgin yanları sanatçılardan, sanat eleştirmenlerinden, sanat tarihçilerinden ve bilim adamlarından öğrenilmektedir. Rönesans'a kadar resim sanatında portre, genellikle kutsal kişileri (Meryem, İsa ve azizleri) ve önemli şahsiyetlerin (krallar, soylular, burjuvalar ve devlet adamları) resimlerini temsil etmiştir. Rönesans'la birlikte portre, bireysellik kazanarak günümüze kadar gelmiştir. 15. yüzyılın portreleri dinin ruhani yanı ile birlikte soyluların da devleti temsil eden gücünü gösterirken 16. yüzyılda portreler bu teamülden kilisenin ruhani tavrını kaldırarak dinî ve dünyevi gücü temsil etmiştir. 17. yüzyıla gelindiğinde portreler, gündelik yaşamdan sahneler olarak görülmeye başlanmıştır. Portre, 18.yüzyılın ortalarına kadar zarafeti ve sevgililerin şımarık yanını temsil ederken 18. yüzyılın sonlarına doğru sanatçılar portrelerle, soyluluğu ve asaleti temsil etmeye başladılar. 19. yüzyılda ise portreleri oluşturan sanatçılar; hiçbir gücün etkisinde kalmamışlar ve özgür bir ortam içinde, sıradan, gündelik olayları resimlerinde yansıtmaya başlamışlardır. Portreler bu gündelik yaşam içinde dinsel olmaktan çıkıp gerçekçi bir anlayış içinde aktarılmaya başlanmıştır. Bu gerçeklik, toplumsal yapı içerisinde nesnel bir niteliğe bürünerek yüzey üzerinde yeni ve farklı anlatım biçim arayışına öncülük etmiştir. Bunun sonucunda artık portre konusu; Natüralizm, Romantizm, Empresyonizm, Ekspresyonizm Kübizm vb. sanat akımlarında ya da eğilimlerinde farklı bir şekilde incelenmeye başlanmıştır. Modernizm ve sonrasında portreler, değişen teknolojik ve bilimsel gelişmelere paralel olarak gelişimini sürdürmüştür. Günümüze gelindiğinde portre, gelişen teknolojik ve bilimsel gelişmelerin etkisiyle farklı biçimlerle ve anlamlarla ifade edilmeye başlanmıştır. Postmodern olarak adlandırılan bu dönemde sanatın konuları çeşitlenmiş ve bu konular farklı sanatsal alanlarla birlikte psikoloji, sosyoloji, antropoloji...gibi alanların etkisiyle eserler çok disiplinli bir görünüm kazanmıştır. Bu değişim, daha önceki dönemlerde olduğu gibi sanatta portredeki temsil anlayışı gündeme gelmiştir. Kavramsal sanat içinde portre temsil anlayışı; beden, enstalasyon, video, performans, fotoğraf, etnik ve feminist sanatla yorumlanmaya başlanmıştır. Sanattaki bu başkalaşma, portrelerde sanatçıların bazılarının kendi bedenlerine çizdikleri şekillerle ifade edilmeye çalışılırken diğer sanatçılar da fotoğraf ve video sanatı gibi görüntüleme tekniklerini kullanarak yansıtmaya çalışmışlardır. Sanattaki bu değişimler sayesinde her türlü malzeme kullanımı gündeme gelmiştir. Bu değişim beraberinde farklı alanların birbiriyle ilişki kurmasına ya da kaynaşmasına sebep olmuştur. 


\section{Geçmişten Yirminci Yüzyıla}

\section{Kadar Olan Süreç İçinde Resim Sanatında Portre}

Portre; bir insanın desen, resim, fotoğraf ve benzeri yollarla tasviri olarak öne çıkmaktadır. Portre konusu, insanın farklı teknikler arayıcılığıyla kendini veya bir başka kişiyi görselleştirmesidir. Portre veya otoportre; İlk Çağ'dan günümüze kadar farklı tekniklerde, üsluplarda değişim geçirerek gelişimini sürdürmüş ve resim sanatının her zaman önemli konuları arasında yer almıştır. Tarihte bilinen en eski portre, 2006 yılında Fransa'nın Angouleme şehri yakınlarındaki Vilhanneur Mağarası içinde bulunan ve 27.000 yıllık geçmişe sahip olduğu tespit edilen bir duvar resmidir (Görsel 1).

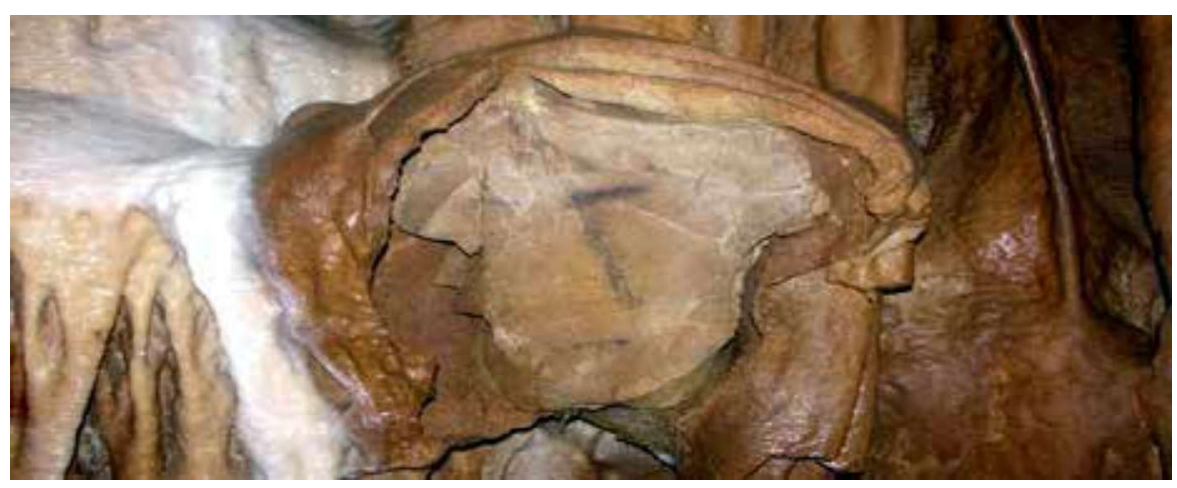

Görsel 1: “İlk Portre Örneği ”, Vilhanneur Mağarası, Angouleme, Fransa

Bu örnekte görüldüğü gibi mağaraların duvarlarına yapılan bu resimleri / portreleri, tarih öncesi insanların kendi belirledikleri biçimlere göre yaptıkları görülmektedir. Portreler şematik ve çizgi hâlinde ele alınmakta ve insan başı oranları ilk zamanlarda gövdeye ve boya oranla çok küçük resimlenmektedir. İlkel insanların resimleri / portreleri ilerleyen zaman sürecinde başın/vücudun orantısız yapıldığı görülmektedir (Turani, 2004: 11). İlkel dönemden Mısır uygarlı̆̆ına gelindiğinde ise portre biçimi daha çok yandan (profilden) şematik bir biçimde resmedilmişlerdir (Görsel 2). Sanatçıların bu resimleri, önemli kişilerin (kralların ve kraliçelerin) öldükten sonra yaşamlarına devam edecekleri inancını yaşatmak amacıyla yaptıkları görülmektedir. Yapılan bu eserlerdeki portreler, gerçekte oldukları gibi değil de çizimi yaptıran kişinin olmak istediği (ideal) şekilde tasvir edilmiştir. Mısır resminde genellikle figürlerin / portrelerin yüzleri profilden, gözleri ise badem şeklinde önden tasvir edilmiştir. Omuzlar; genişliğini göstermek için önden verilirken, gövdenin geri kalan kısmı dörtte üçlük yana doğru dönmüş vaziyette betimlenmiştir. Kalça, baldırlar ve ayak kısımları da profilden resmedilmişlerdir (Brever ve Teeter, 2011: 213). 


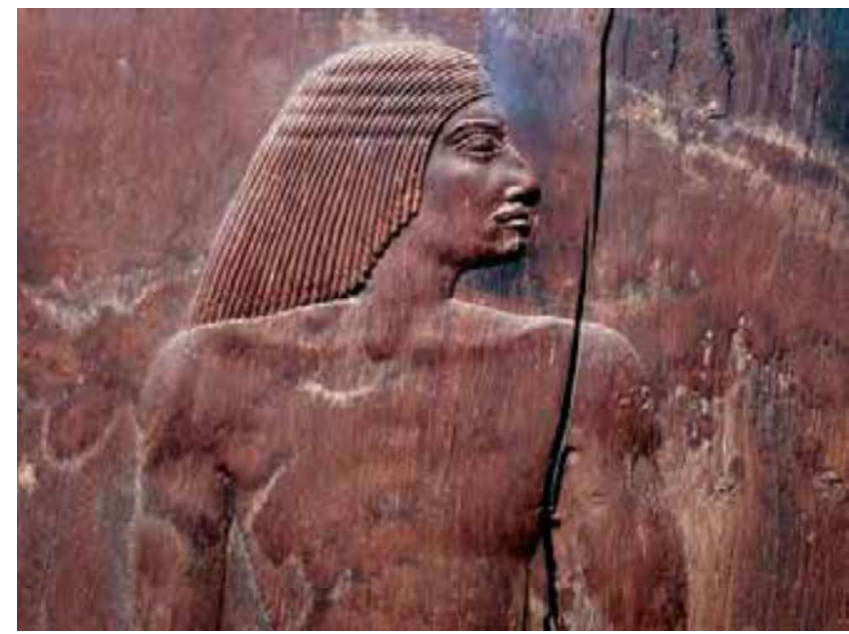

Görsel 2: "Hesire'nin Portresi”, gömütün tahta kapısının bir bölümü. İ̈, 2700, Kahire Müzesi, Mısır.

Misır uygarlığında bu sanatsal gelişim sürecinde devam eden diğer bir uygarlık da Yunan'dır. Yunan uygarlığı sanatı üç dönemde incelenmektedir: Arkaik Dönem, Klasik Dönem ve Helenistik Dönem. Sanatsal oluşum bu üç dönemde gelişim göstererek devam etmiştir. Yunan uygarlığında portre iki şekilde tasvir edilmiştir. İlki, antik vazoların üzerine yapılan resimlerde ve ikincisine de Antik Yunan heykellerinde rastlanmaktadır. Antik vazo resimlerinde anlatımcı stilize edilmiştir ve insan figürleri/portreleri dikkat çekmektedir ( Görsel 3).

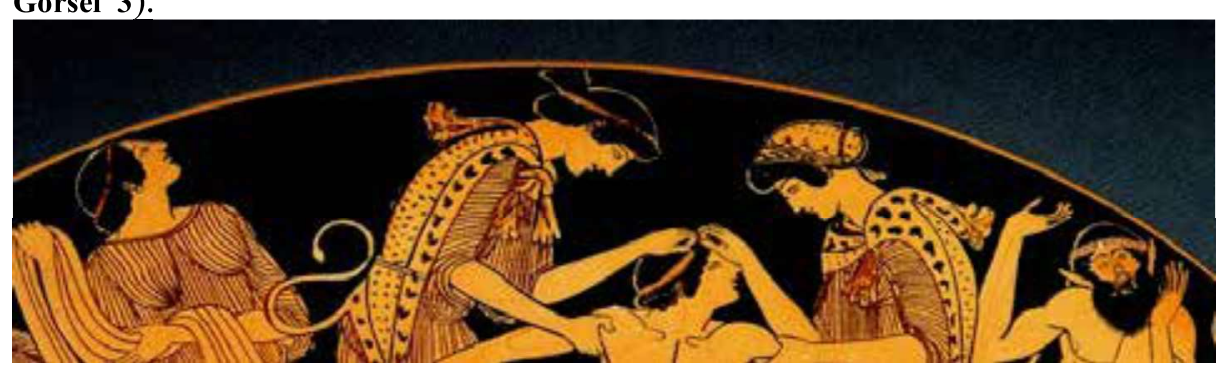

Görsel 3: Kırmızı figürlü Yunan vazo resminden bir detay, "Pentheus'un Ölümü”, MÖ,420.

Roma döneminde her ne kadar özgünleşme çabaları söz konusu olsa da resim sanatı, Yunan sanatının etkilerini taşımaya devam etmiştir. Özellikle Yunan'ın Helenistik dönemi, Roma sanatında etkisini sürdürmüştür. Roma dönemi resim sanatı, daha çok duvar resminde betimlendiği bilinmektedir (Görsel 4). Bu 
resimlerde Roma-Helenistik karışımı bir kompozisyon şekli göze çarpmaktadir (Turani, 1999: 199).

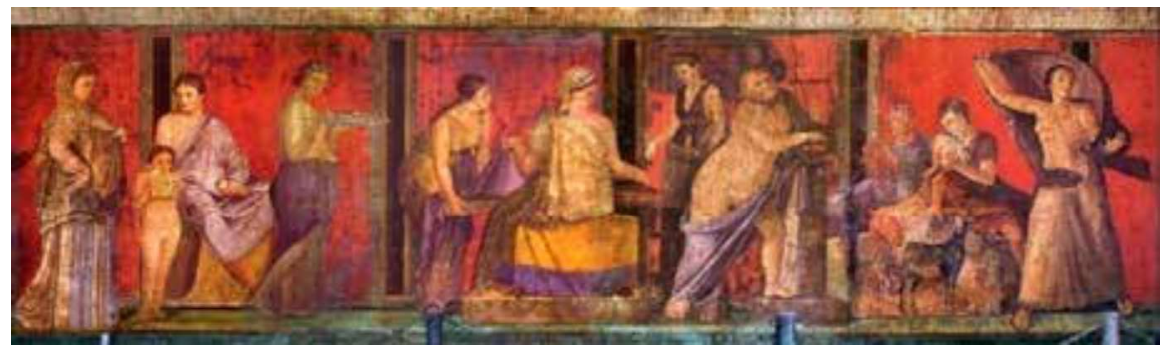

Görsel 4: Sanatçısı bilinmiyor, "Yemek Odası", duvar freski (ayrıntı), MÖ, 60-50, 162 cm, Pompei, İtalya.

Roma sanatında sanatçıların, daha çok duvar resmi tekniğini kullandıkları görülmektedir. Bunun yanında duvar resmi kadar yaygın kullanılmayan mozaik ve bal mumu tekniğiyle yapılmış resimlerde görülmektedir. Bal mumu ile yapılan bu resim tekniği daha sonraları Bizans'ta ve Hristiyan ikonalarında görülmeye başlanmıştır (Turani, 1999: 200). Bu çeşitlilik, Bizans sanatının değişik açılardan sunulmasına sebep olmuş ve sanatta da bu biçimde yansıma olanağı bulmuştur. Bizans sanatında özellikle de resim alanında konu olarak din ön plana çıkmıştır. Dinin ön plana çıkması ve başka inançları terk edip tek inanç doğrultusunda gelişim gösteren dinî söylemler resim sanatında uygulama alanı yaratmıştır. Bizans resim sanatındaki görsel ögelere bakıldığında ise tek din olan Hristiyanlık inancının alegorik betimlemeleri görülmektedir. Bu betimlemelerin mozaiklerde, ikonalarda ve yontu tekniklerinde oluştuğu bilinmektedir. Özellikle de mozaik tekniği geniş bir alanı kapsamıştır ( Görsel 5-6).

Bizans sanatından sonra Romanesk ve Gotik üslup gelmektedir. Bu üsluplarda genellikle din konusu önemli bir yere sahip olmuştur. Her iki üslupta sanatsal biçim, daha çok mimari yönde gelişim göstermiştir. Romanesk sanatında resim alanında sadece vitray tekniğinin kullanıldığı görülmektedir (Görsel 7). Gotik sanatta; özellikle resim alanında vitray, kitap resimleme, minyatür ve altar panosu üzerine guaj/tempera tekniği ile yapılan çalışmalar dikkat çekmektedir (Görsel 8).

Rönesans'a gelene kadar resim sanatı dinin etkisinde kalmış ve bu doğrultuda gelişim göstermiştir. Erken Rönesans ile birlikte portre gerçekçi bir anlayışla betimlenmeye başlanmıştır. Bu dönemde portrelerin ilk örnekleri profilden resimlendiği görülmektedir. Bu portrelerde kişilerin psikolojik durumları ya da ruh hâllerinin yansıtılmaya başlandığı dikkati çeker (Uysal, 2009: 109). Rönesans'la birlikte Batı'da, portrenin önem kazandığı ve en çok ilgi gören türlerden biri olduğu bilinmektedir. 
Portre konusuna daha erken dönemlerde rastlansa bile portrenin yaygın kullanımı şüphesiz Rönesans'la tarihlendirilebilir. Rönesans Dönemi; farklı ülkelerdeki gelişimi sayesinde, konu çeşitliliğin artmasına ve özellikle de portre konusunun Rönesans sanatçıları tarafindan incelenmesine neden olmuştur. Bu popülerlik boyutu ve kullanımı portreyi etkilemiş ve çeşitli tarzlarda (ekoller) çalışma imkânı sağlamıştır Rönesans sanatçılarının yapmış oldukları portrelerde, sanatçıların çizimlerine katkı sağlayan modellerin idealize edilmiş yüz formları dikkat çekmektedir. Sanatçılar, betimlemiş oldukları eserlerde bireysel kimliğin yansıtılması çabası içinde olmuşlardır. Sanatçıların bu çabası da portrelerde "eşsiz bireysel kimlik düşüncesinin" ortaya çımasına sebep olmuştur. Bu yüzyılda portre konusunu inceleyen pek çok sanatçı, kendi bireysel çalışmalarını yapmıştır ( Görsel 9-10).

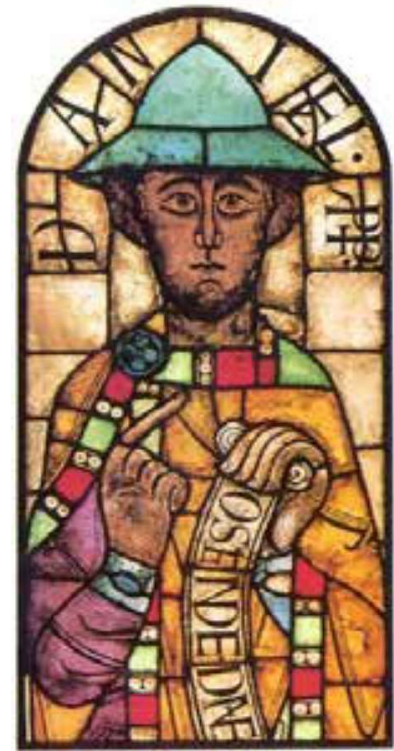

Görsel 7: Sanatçısı bilinmiyor, Aziz Daniel, vitray tekniği, (Roman dönemi) Bayern, Almanya.

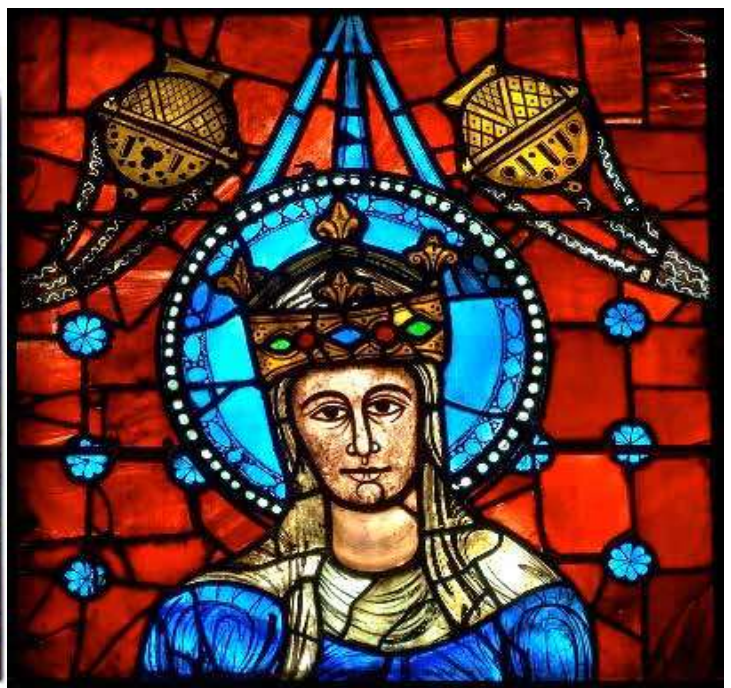

Görsel 8: Sanatçısı bilinmiyor, Belle Verriere, vitray tekniği Gotik Dönem), 1180-1220 Chartres Katedrali, Paris, Fransa.

Bu yüzyıl içinde Rönesans'a karşı bir hareket olarak gelişen üslup Maniyerizmdir. Rönesans'ın ideal, uyumlu biçim anlayışı ve gerçeklik arayışının karşısında olan düşünce yapısının görselleşmiş bir şekli olarak bu resimlerde sanatçılar, mistik ve sembolik bir anlatımla kendi iç dünyasına yönelmişlerdir (Şentürk, 2012: 122). Bu üslubun resim anlayışı, deforme edilmiş figürler (portreler), resimsel mekânın belirsizliği, dikey-yatay hareketler dışında kavisli ya da yuvarlak hareketlerle şekillenmektedir. Ayrıca bu sanat hareketinde, yer çekimi, perspektif ve mekân kavramı önemini yitirmektedir ( Görsel 11-12 ). 


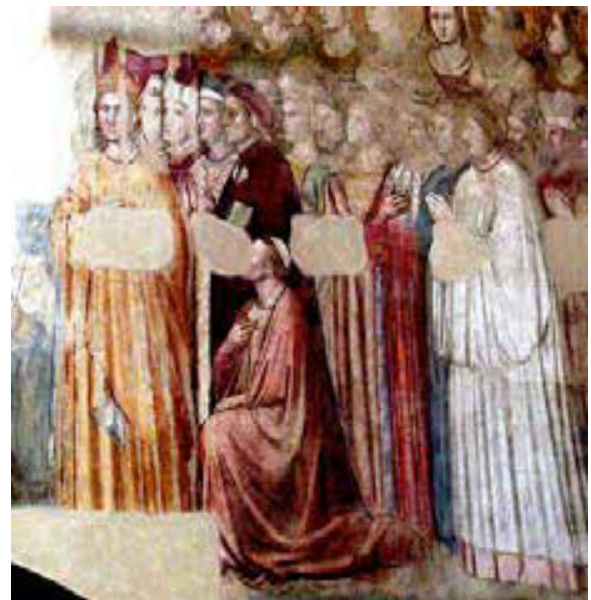

Görsel 9: Giotto De Bondone, Mahșer, Duvar Resmi 14.Yüzyıl, Ulusal Bargello Müzesi, Floransa, İtalya. Ağacından Pano Üzerine, Londra Ulusal

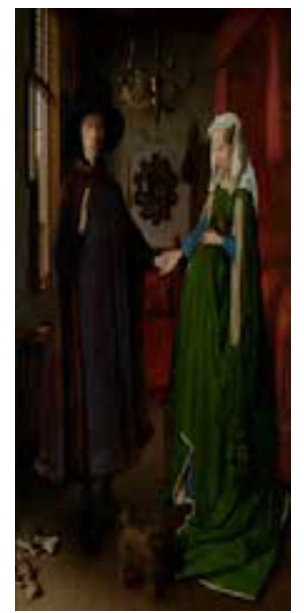

Görsel 10: Jan Van Eyck, Arnolfini'nin Evlenmesi, 1434 59,7 x 81,8 cm, Meșe Galerisi, İngiltere.

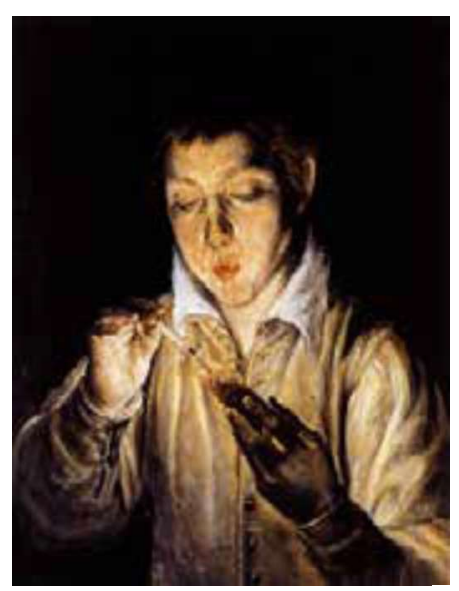

Görsel 11: El Greco, Aleve Üfleyen Çocuk, Ahşap Üzerine Yağlı boya Özel Koleksiyon .
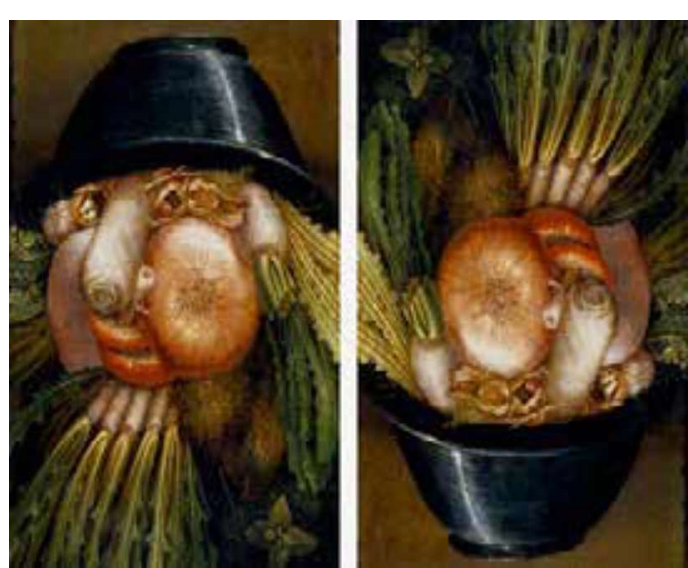

Görsel 12: Giuseppe Arcimboldo,SebzeAdam/ Tabak, 157,1570-1575, Tuval Üzerine Yağlı boya,Civico Müzesi, Cremona, İtalya. 
Öğr. Gör. Dr. AHMET UZUNER

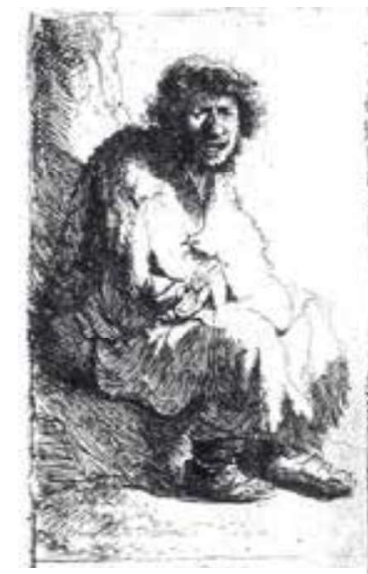

Görsel 13: Rembrandt Van Rijn, Dilenci Olarak Kendi Portresi, 1630

Gravür, 7x1 1,6 Rijks Müzesi, Amsterdam, Hollanda.

On yüzyılda portre sanatçıları daha çok psikolojik gerçeğe önem vermeye başladılar. Bu yüzyılda, barok dönemde portre anlayışı dönemin sanatsal gelişimi içinde değerlendirilir. Barok dönemdeki resim anlayışında gerçeklikten çok düş gücünün önem kazandığg, abartılı duyguların üzerinde durulduğu ve teatral özelliklerin figürlere (portrelere) yansıdığı biçimdedir. $\mathrm{Bu}$ sanatçılar idealleştirme ve dekoratifleştirmenin yanı sıra bireysel özellikleri de betimlemeye çalıştılar ( Görsel 13).

17. yüzyılda, rokoko portre sanat anlayışında sanatı destekleyen kralların yerini burjuva almıştır. Bu sanat biçiminde küçük kıvrımlar, yuvarlak biçimler ve bazen aşırı süslemeler görülmektedir. Işık kullanımı her yana yayılan zengin bir süsleme anlayışına dayandırılmakta dir ( Görsel 14 ).

Sanat alanındaki gelişim, beraberinde yeni yaklaşımların doğuşuna sebep olmakta ve bu oluşumlar da sanat alanında farklı dönem ve tarzların görülmesiyle sonuçlanmaktadır. Neoklasisizm, akıl ve dünyanın akıl yoluyla kavranmasını öncelik olarak gören aydınlanma görüşüyle ortaya çıkar ( Görsel 15).

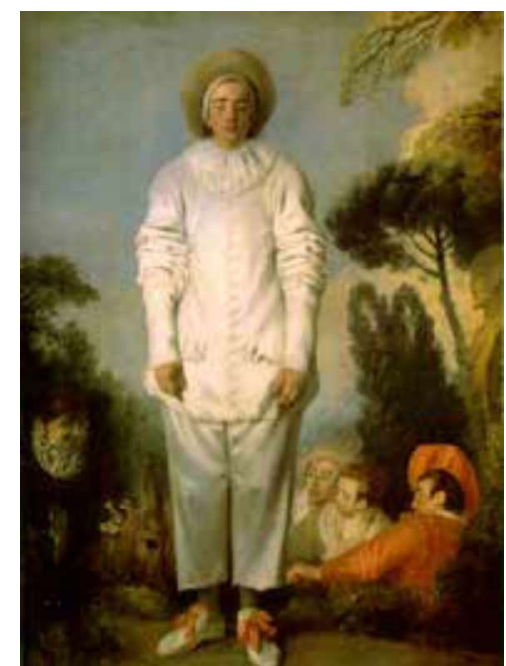

Görsel 14: Antoine Watteau. "Gilles" 1718-19, tuval üzerine yağlı boya, 149x184cm, Louvre Müzesi, Fransa.

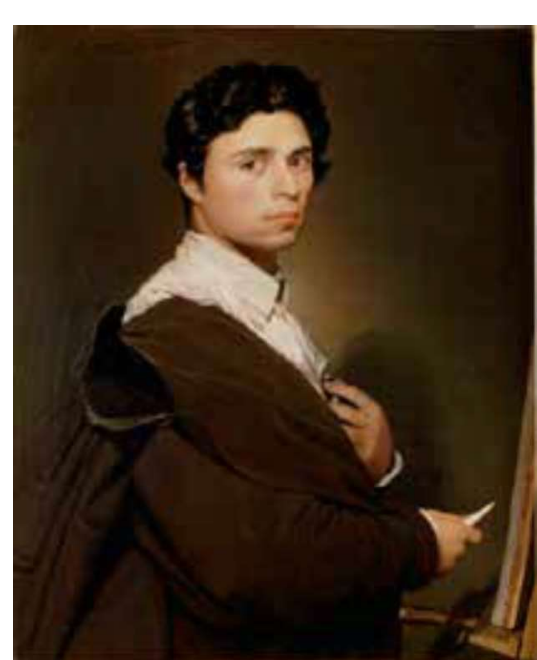

Görsel 15: Auguste Dominique İngres, Otoportre, 1804, yağlı boya, $61 \times 78 \mathrm{~cm}$, Conde Müzesi, Oise, Fransa. 


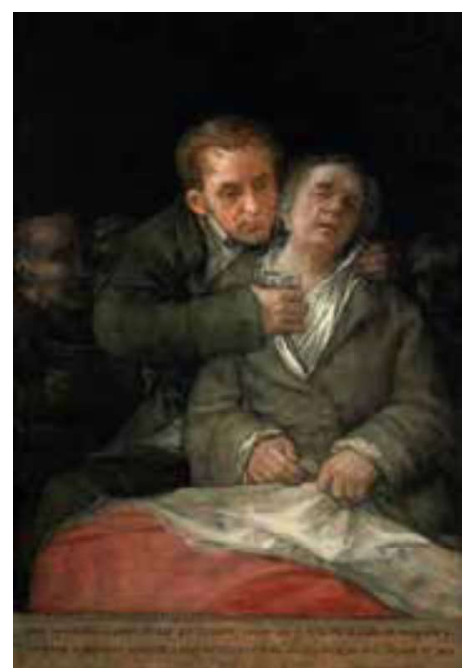

Görsel 16: Francisco Goya, Dr. Arrieta' la Kendi Portresi Tuval Üzerine Yağlı boya, 79,1 x 115,6 cm, Minneapolis Sanatlar Enstitüsü, Minneapolis, Amerika.

Figür ve portre Antik Çağ'a ve alegorik özelliklere göre biçimlenmektedir. 18. yüzyılda konu olarak peyzajlar, portreler, çıplak (nüler) ve mitolojik konular işlenmiştir. Bu sanat akımı içinde resimler ve özellikle de portreler doğru anatomik ve optik gözleme dayanmaktadır. Portrelerde katı bir desen ve soğuk renkler egemendir. Her yönden gelen işık ön planda olmuştur.

Klasisizmin katı sanat anlayışına karşı çıkan romantizm döneminde sanatçılar toplumsal ve siyasal olayları kendine özgü bir dil ile konu edindikleri görülür. Bu dönemde coşkulu konular, ş̧ıgölge temeline dayalı resimler öne çıkmaktadır. Portre konusu da duygusal yönünü belli eden yüz biçimleri olarak kendini göstermektedir (Görsel 16).

Romantizmin duygusal ve coşkucu yönüne tepki olarak doğan akım realizmdir. Bu sanat akımında gerçekçi tarzda portre vb. konuların işlendiği görülmektedir. $\mathrm{Bu}$ akımın içinde portre konusunda görülen yüzlerin doğal hâlleriyle betimlendiğidir. Bu dönemde yer alan sanatçılarda eserlerini, toplumsal yapıya göre oluşturdukları bilinmektedir ( Görsel 17).

Realizmin bitişiyle birlikte arkasından devam eden sanat akımı izlenimciliktir. İzlenimcilik sanatı içinde oluşan resimsel plastik değer; gün 1şığının, rengin ve gölgenin güçlü bir etki bırakmasını sağlamıştır. İzlenimciler rengi belirgin ve parlak renkler olarak kullanmayı tercih etmişlerdir. Portre de bu akımın plastik özelliklerine göre şekillendiğidir (Görsel 18).

İzlenimcilik akımının devamında gelişim gösteren art-izlenimcilik, sembolizm, fovizm, dlşavurumculuk, kübizm, fütürizm, dadaizm,

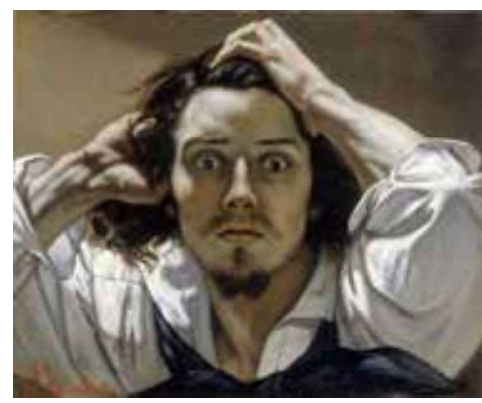

Görsel 17: Gustave Courbet, Otoportre, 1844 Tuval Üzerine Yağl1boya, 45 x $55 \mathrm{~cm}$, Özel Koleksiyon. yeni nesnelcilik, gerçeküstücülük ve devamında gelişim gösteren, pop-art, foto gerçekçilik, yeni gerçekçilik gibi akımlar / üsluplar dikkati çekmektedir. Görüldüğü gibi portrenin sanatçılar tarafından farklı yorumlanmaları dikkat çekmektedir. Modernizm'e kadar ki süreçte portre konusunun birbirini takip eden 
sanatsal gelişmeler doğrultusunda olduğu anlaşılmıştır. 20.yüzyıla gelindiğinde ise birden fazla sanat akımlarının / üsluplarının portre konusuna yeni kullanım alanları yarattığı görülmüştür.

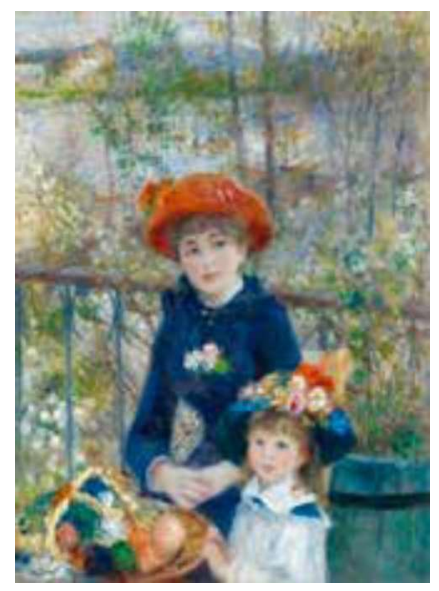

Görsel 18: Pierro- August Renoir, İki Kız Kardeş, 1881, Tuval Üzerine Yağlı boya $80.9 \times 100.4 \mathrm{~cm}$, Chicago Sanatlar Enstitüsü, ABD.

\section{20. Yüzylda Sanatta Portre}

Biçimciliğe karşı durmanın ötesinde minimalistlerin, yeni dadacıların ve pop sanatçıların önermelerini sorgulayan eğilimler 20. yüzyılın ikinci yarısında karşımıza çıkmaktadır. Bu yeni anlayışla üretilen uygulamalar; resim, heykel, fotoğraf, mimari, tasarım gibi tek disiplin ile açıklanamadığı için artık bu tür disiplinlerin sınırları yumuşamış, neredeyse yok olmuştur. Zira bu, yeni bir dönemin alanıydı. Plastik sanatların içinde yer alan disiplinlerin birbirleriyle ya da diğer sanat alanları ile yaşadıkları etkileşim sonucunda ortaya çıkan bu muğlaklık ile disiplinler bir başka disiplinden rol kapmaya başlamıştır. Bunun sonucunda çok sesli, çoğulcu ve multidisiplinli yeni ifade biçimleri ortaya çıkmıştır.

Yeni dönemdeki yapıtlar, resim ve heykel gibi bilindik geleneksel sanat biçimlerinden farklı olarak oluşturulmuşlardır. Bu farklılık, sanat pratiklerinde geniş yelpazeler açılmasına katkı sağlamıştır. Hem kullanılan malzemede sanatçının tercihleri çeşitlenmiş; hem de Felsefe, Sosyoloji, Mühendislik gibi tüm bilim dallarından faydalanılarak hayat ve sanatın aynı pota da buluşturulma olanağı sağlanmıştır. Bu bağlamda, sanat-toplum ilişkilerinde iyileşmeler yaşanmış ve toplumun (izleyicinin) sanata ilgisi ve sanata karşı sorumluluğu da değişmiş̧tir. Artık izleyici sanat nesnesinin üretim süreci itibariyle işin 
içine girmiş ve onun doğrudan bir parçası hâline gelmiştir. Böylelikle sanat nesnesi, sanatçı ve izleyicinin rolü yeniden biçimlenmiştir. Bu gelişmeler eşliğinde Yerleştirme (Enstalasyon), Eylem sanatı, Yoksul sanat, Vücut sanatı, Arazi sanatı, Oluşumlar (Happening), Kavramsal sanat, Süreç sanatı, Gösteri sanatı vb. farklı sanatsal oluşumlar meydana gelmiştir. Yeni sanatsal ifade biçimleriyle birlikte sadece izleyicinin rolü değişmemiş, aynı zamanda konvansiyonel estetik anlayış yerini "ilişkisel estetik" anlayışına bırakmıştır. Sanatçının kutsandığı modernist anlayışın yerine, "Herkes sanatçı olabilir." felsefesiyle sanat nesnesinin üretim süreci kutsanmış, bağlam ve uzama dair sorgulamalar önem kazanmıştır. Böylece sanat “beyaz küp” "ün sınırlarının dışına çıkmıştır. Sanat eserinin sergilendiği mekân bakımından; yapıt, sanatçı ve küratöryal anlamda dönüşümler meydana gelmiştir. Çünkü Robert Smithson'ın binlerce metrekarelik alanı kaplayan Spiral Jetty eserini sergileyebileceği bir beyaz küpü bulması neredeyse imkânsıza yakındı. Ancak burada önemli olan, böylesi devasa bir çalışmayı sergilemek için mekânın bulunmasından ziyade mental anlamda yaşanan gelişmelerdi.

Disiplinler arasılık doğrultusunda 20. yüzyılda özellikle 1960'ların sonunda, tüketimi çekici hâle getirmek için; reklamlar, renkli afişler, hatta resimli dergiler ve romanlar kullanılmaya başlanmıştır. Buna benzer malzeme kullanımı pop sanatının, dada sanatının benzer yönlerini/yöntemlerini kullanmasında görülmüştür. Bu dönemde kolaj ve asamblaj tekniği tekrardan gündeme gelmiş ve pop art sanatçılar tarafindan kullanılmıştır. Kitle kültürü özelliklerine göre biçimlenen bu sanat akımı, geniş kitlelere ulaşabilmek için hem medyayı hem de farklı sanat güçlerini de bir arada kullanmıştır. Bu bira adalık disiplinler arasılığın kullanımıyla gerçekleşmiştir. "Pop sanatta, klasik sanat di-

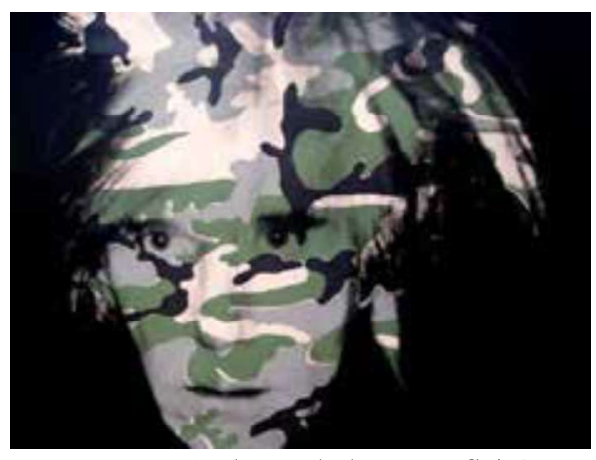

Görsel 19: Andy Warhol, "Kamuflaj Otoportre", tuval üstüne serigrafi mürekkebi ve sentetik polimer boya, 1970, 208,3×208,3 $\mathrm{cm}$. Metropolitan Müzesi, New York, ABD. line yabancı olan malzemeler kullanılarak; teksir, baskı, resim, fotoğraf, kolaj ve üç boyutlu yapitlar üretilmiştir. Sanatçılar örneğin; Roy Lichtenstein çizgi roman kareleri çizmiş, Andy Warhol da önemli ikonların (popüler kişilerin) tüketim mallarının ve gazete kupürlerinin imgelerini kullanarak serigrafilerini yapmış, Robert Rauschenberg ve Jasper Johns ise tüketim toplumunun sembollerini kullanarak resim ve heykeller biçimlendirmişlerdir" (Y1lmaz, 2015: 1008). 
Bu sanatçılar içinde özellikle; ressam, film yapımcısı, yönetmen, prodüktör, yazar, pop-art ve popüler kültürün en önemli ikonu Andy Warhol'dur. Warhol; döneminin politikacılarını, yazarlarını ve modern tüketim kültürü içerisinde yer alan ünlülerin veya sıradan insanların portrelerini görselleştirmiştir. Sanatçının farklı disiplinleri ve malzemeleri kullanarak oluşturduğu "Kamuflaj Otoportre" adlı eser iyi bir örnektir (Görsel 19). Bu örnek çalışmada Warhol, yaşamı boyunca çalışmalarında kendi yüzünü birçok kere betimlemiştir. Sanatçının tuval üzerine serigrafi baskı tekniğiyle yapmış olduğu ikili ve dörtlü setler hâlinde grup portreleri yanında sentetik polimer zemin üzerine sanayi boyası ile oluşturduğu tekli ve ikili ünlü otoportreleri de bulunmaktadır (Thompson, 2014: 376).

Disiplinlerarasılığın etkin uygulamalarını gördügümüz dönemin diğer önemli sanatçısı da Robert Rauschenberg'tir. Sanatçı, sanatı ve bilimi bir araya getirerek çalışmalar yapmıştır. Rauschenberg çalışmaları sırasında bilim insanlarıyla birlikte hareket etmiştir. Bu bilim adamlarından biri olan Billy Kluver, Rauschenberg ile birlikte Sanat ve Teknolojide Deneyler (EAT) adlı bir organizasyon kurarak çalışmalarda bulunmuşlardır. Böylelikle sanatçılarla mühendislerin birlikte meydana getirdikleri eserlerin uygulamayla ve yaratıcılıkla
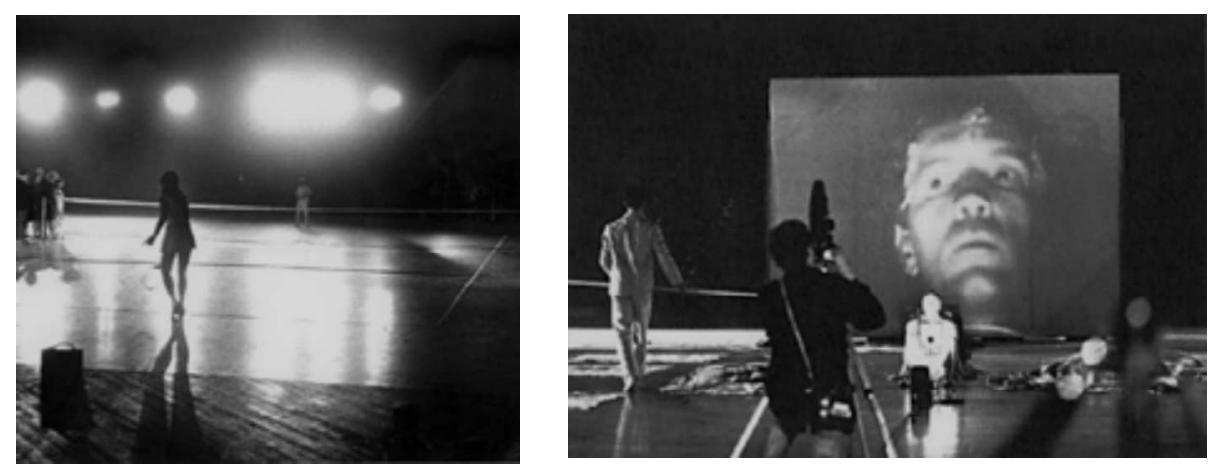

Görsel 20: EAT, Robert Rauschenberg, Open Score, 9. Akşam, Tiyatro ve Mühendislik Ortak Çalışması, 1966.

harmanladığ yeni bir ürün olarak ortaya çıkmıştır. Farklı disiplinlerdeki çok seslilik diğer sanatçıların ilgisini çekmiş ve farklı alandaki insanlarla ortak çalışmalar yapma fikrinin önemi artmıştır. Örneğin; 9. Akşam adlı yapıt, görsel sanatçıların, dansçıların ve müzisyenlerin farklı meslekteki insanların ortak çabaları sonucunda oluşturulmuştur (Görsel 20).

$\mathrm{Bu}$ çalışma; estetik ve teknik yönden tam bir başarı elde edilmemesine karşın, sanatçılarla mühendislerin bir arada yapabilecekleri fikri bu etkinlikte açıkça fark edilmiştir. Yapılan çalışmalar, sanat ve teknolojinin birleşimiyle 
sonraki yıllarda görülecek olan Happening ve Performans diye adlandırılacak sanat biçimlerinde daha geniş uygulama alanı bulmuştur (Şahiner, 2015: 9193).

Resim, fotoğraf vb. alanlarda incelenen konular (portre, manzara, natürmort vb.) yaşamdaki gerçeğin aynısı değil, dönüştürülmüş veya değiştirilmiş görüntüleridir. Resimde veya fotoğrafta ise konular, resmi yapanın ya da fotoğrafi çekenin yorumuyla oluşmaktadır. Bu konuların işlenişi hem teknolojik hem de malzeme yönünden değişiklik göstermektedir. Sanattaki farklılığın özellikle teknolojik gelişim sayesinde sürdüğü görülmektedir. Fotoğrafın bulunmasıyla birlikte, bu çeşitliliğin sanat alanlarında değişik tekniklerde veya yöntemlerde yansıdığı gözlenmektedir.

Söz ya da sözcüklerde bu disiplinlerarası sanat içinde önemli bir yere sahip olmuştur. Bu sanat şeklinde yapılan çalışmalar, söz ve sözler görsel etkiyi izleyicinin düşünmesine/anlamlandırmasına bağlı olarak gelişim göstermektedir. "Bunun içindir ki farklı disiplinler içinde gelişim gösteren kavramsal sanat her gün karşılaştığımız şeylerle, onlara uygun gelen durumları bir araya getirerek farklı şekilde sunmaktadır. Disiplinler arası sanatta kavramsal bir çalışma, metin ve nesnel bir biçim olarak tasvir edilmemiş olsa da farklı araçlar (baskı tekniğiyle, ses manipülasyonlarıyla, dijital miksajla) yardımıyla yeni bir yapıtın karşımıza çıktığı görülür. Burada sanat biçiminde gördüğümüz kadarıyla fikirlerin de tek başlarına bile sanat eseri niteliğinde olabileceği gerçeği sunulmaktadır. Bu kavramsal sanat yapıtlarının anlamları derin ve karmaşık olduğu gibi sıradan da olabilmektedir." (Yılmaz, 2015: 1009).

1950'lerden itibaren sanattaki teknolojik gelişmeler hızlı bir sürecin oluşmasına sebep olmuştur. Bu hızlı gelişimle birlikte sanat alanları ile diğer alanlar birbiriyle bir etkileşim içinde olmaya başlamıştır. Belirtildiği gibi disiplinler arası sanat bu etkileşimin sonucu olarak ortaya çıktığı belirtilmektedir. Disiplinler arası sanatı birden fazla sanat akımını/üslubunu barındırdığ 1 için tek sanatsal bir bakışla çözümlemek olanaksızdır. Çünkü disiplinel anlam, çok kültürlü ve geleneksel estetik kurallarına ya da geleneksel resim ve heykel anlayışının dişında kalır.

Örneğin performans sanatı kompozisyon, oran-orantı, leke, çizgi, doku, 1şık-gölge vs. kriterlerine uydurulamaz ve bu geleneksel kurallar üzerinden okunamamaktadır. Her şeyden önce doku uyuşmazlığı ortaya çıkar. Bu, B kan grubu taşıyan bir hastaya A grubu kandan vermek gibidir (Görsel 21). Performans sanatının uygulanış biçimi, sanatçının yaşamsal deneyimleri (politika, psikoloji ve gündemde olan diğer meseleleri) kendi bedenini kullanarak izleyiciye aktarmasıdır. Bu gösterim; hazırlıklı veya doğaçlama, dans edilerek, şarkı söyleyerek, pandomim gibi tiyatral biçimleri kullanılarak ifade edilmek- 


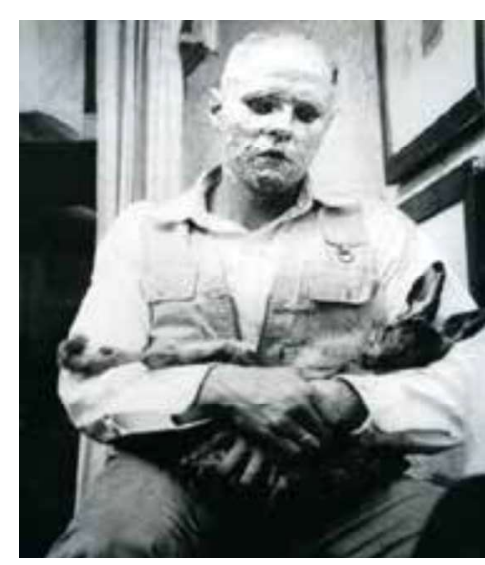

Görsel 21: Joseph Beuys, Ölü Bir Tavşana Yapıtlar Nasıl Anlatılır, 1965, Yaklaşık 120 dk. Süren Performans Çalışma, Schmela Galeri, Almanya. tedir (Hodge, 2014: 184). Bu performans sanatı tekrarlanmadığı için ya fotoğraflanmakta ya da videoya çekilerek kayıt altına alınmaktadır. Performans gösterisi; iki veya üç eşya parçası, az bir dekor ve gösterime uygun olan bir kostümle bir mekân içinde veya dışında yapılmaktadır. Bu performans gösterisinde sanatçı, gösterinin ana oyuncusu ve gösterinin merkezinde yer almaktadır (Carlson, 2013: 27).

Performans sanatında görüldüğü gibi uygulama alanının çok geniş olduğu görülmektedir. Daha önce belirtildiği gibi, performans sanatçıları yapmış oldukları çalışmaları genellikle videoya kaydederek veya fotoğrafa çekerek arşivledikleri bilinmektedir.

Görüldüğü gibi bu sanat biçimi de farklı malzeme, araç-gereç, internet, bilgisayar, fotoğraf ve teknoloji gibi farklı disiplinlerden yararlandığı göze çarpmaktadır. Bir önceki konuda da video gibi teknolojik gelişme başka bir sanat eğiliminin ortaya çıkıșını sağlamıștır. Bu sanat biçimi de video sanatıdır. Video sanatı, çok yeni olan bir teknolojik gelişmedir ve bu gelişme 1960'lı yillarda ortaya çıkmış ve 1980'lerin ortalarında da önemini yitirerek etkisini kaybetmiştir. Video bu dönemde hem kitle iletişim aracı hem de filmlerde, tiyatro oyunla rında, gösterilerde ve birçok sanatsal etkinliklerde kullanılmıştır.
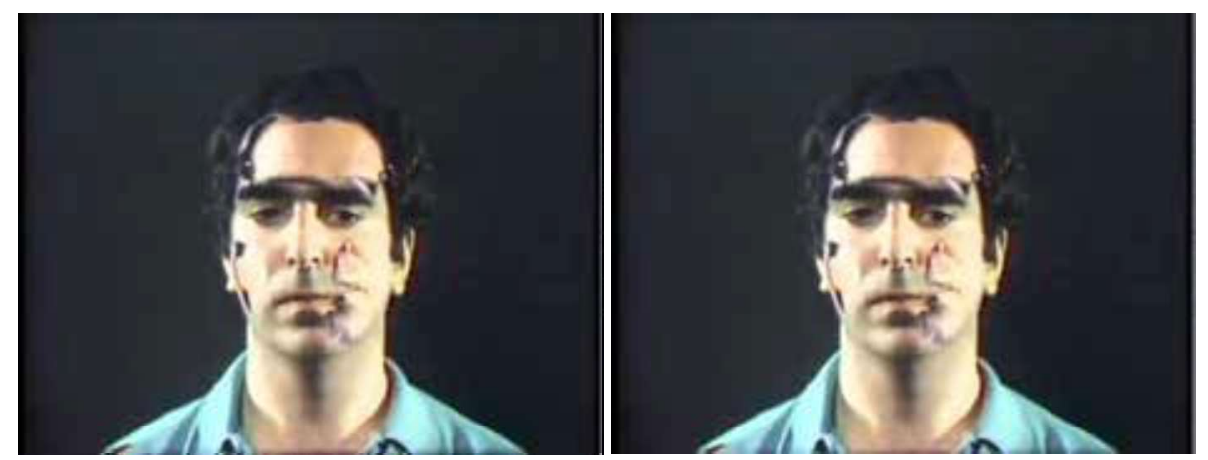

Görsel 22: Peter Campus, "Üç Geçiş (Three Transition)", video kamera, 1973. 
Bu sanatsal gelişim özellikle 1980 ve sonrası yeni sanat şeklinin bir habercisidir (Altunay, 2013: 5) ( Görsel 22).

Disiplinler arası yaklaşımın video sanatında kullanıldığı gibi enstalasyon sanat biçiminde de kullanıldığ bilinmektedir. Bu sanat şeklinde her türlü malzemenin kullanıldığı görülmektedir. Çalışmalar; resim, heykel, video, 1şık vs. gibi farklı sanatsal biçimleri kullanılarak oluşmaktadır. Bu eserler, sadece farklı malzeme kullanımından doğan görsel etkiyle kalmayıp insanın farklı duyular tarafından algılanmasını sağlamaktadır. Bunun yanında da enstalasyon sanatında mekân önemli bir yere sahip olmuştur. Mekân, sanatsal düzenleme içinde veya bağımsız bir şekilde yer almakta ve bunun sonucunda eser-mekân bütünlügü elde edilmektedir. Bu sanat biçiminde mekân mimari bir öge olarak öne çıkmaktadır. Enstalasyon çalışmalarına bakıldığında bu bütünlük açıkça görülür.

Görüldüğü gibi bu sanat biçiminde de farklı disiplinlerin kullanıldığı (heykel, mimari) göze çarpmaktadır. Bu farklı disiplinlerin kullanımı yeni bir sanat dilinin kullanım şeklini göstermektedir. Disiplinler arası sanatın modern sanat üsluplarının kullanımına bakıldığında, bu sanat biçimlerinin disiplinler arası sanatı beslediği ve yeni bir sanat dilinin oluşumuna katkı sağladığı görülmektedir. Disiplinler arası yaklaşımlarla geniş yayılma alanı bulan farklı malzeme kullanımı, günümüz sanatı (Postmodernizm) içinde yer alan farklı disiplinlerin birbiriyle kaynaşarak oluşturduğu bir görüntü vermektedir.

Postmodern sanat birbiri ile aynı olmayan çoğulcu temel biçimlerden oluşmaktadır. Sanatta temsil, doğadan koparak kavramsal temsil biçimlerine dönüşmüştür. Bu dönüşüm temsil biçimini değiştirmiş; tuval, boya ve geleneksel malzeme yerine her türlü malzeme kullanılmaya başlanmıştır. Her nesne sanat yapıtı olma özelliğini kazanmıştır. Popüler, kitch ve gündelik olan sanat nesnesi ya da konusu, temsil özelliği elde etmiştir. Sanatın estetik kriterleri bulanıklaşmış, yaşam estetikleşince estetiğin ne olduğu ya da olmadığı tartışma konusu olmuştur (Alp, 2013: 58).

Postmodern sanata bakıldığında artık sanat biçimlerinin veya pratiklerinin birbiriyle kaynaştığı görülür. Yapılan çalışmalarda; resimde, heykelde, enstalâsyonda, mimaride vb. sanatsal formların karışımı melez bir görüntü verdiği ve bu görüntünün belirli bir sanat formunda sınıflandırılmayacağı bilinmektedir. Bununla birlikte resim ile heykelin bildiğimiz terimlerle tanımlanmasının oldukça güç duruma geldiği görülmektedir (Whitham, 2013: 111). 1960'larda yeni gerçekçilik; performans, video sanatı gibi sanatsal eğilimlerde görülen çoklu sanat anlayışı, 1980'lerle birlikte yaygınlaşarak resim, heykel, grafik, seramik, fotoğraf vb. alanlarla etkileşimi ile daha yoğun bir noktaya ulaşmıştır. XX. yüzyılda yaşanan toplumsal olaylar, konu çeşitliliğinin artmasına da sebep olmuştur. Bu konulardan biri olan portre, sanatçıların farklı ifade biçimlerine 
olanak sağlamıştır. XX. yüzyılda sanatçılar portreleri; kimlik, cinsiyet, siyaset, psikoloji, sosyoloji, antropoloji vb. konular üzerinden incelemeye başlamışlardır. Bu konuları eserlerinde inceleyen pek çok sanatçı olmuştur. Bu sanatçılar arasında; Marc Quinn, Wim Delvoye, Kerry J. Marshall, Yasumasa Morimuro, Marlene Dumas, Jenny Saville, Tony Oursley ve Zhang Huan, Kader Attia, Orlan, John Stezaker, Wangechi Mutu, Annegret Soltau, Fred Tomaselli, Ellen Gallagher, Vik Muniz, Banksy, Benjamin Edwards ve Harold Cohen gibi isimler sayılabilir. Yukarıda bahsedilen sanatçılar içinde 1960'lardan itibaren eser vermeye başlayan ve günümüze kadar devam ettiren sanatçlar da bulunmaktadir.

Bu sanatçılardan ilki Marc Quinn'dir. Sanatçının yapmış olduğu Sir John Sulston adlı portre çalışması ilgi çekicidir. (Görsel 23). Bu portre; Sir John Suls-

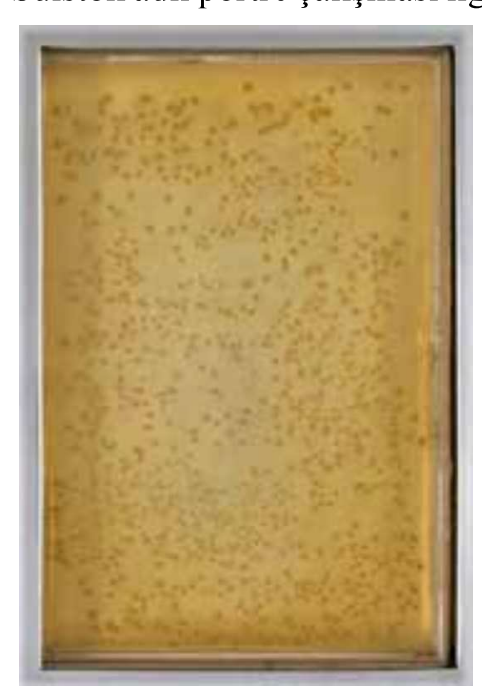

Görsel 23: Marc Quinn, A Genomic Portrait:Sir John Sulston 2001, Paslanmaz Çelik, Polikarbon Agar Jel, Bakteri Kolonileri İnsan İnsan DNA's1. ton'un DNA'sından oluşan bir çalışma olarak ön plana çıkmaktadır.

Çalışma, DNA-kimlik ilişkisinin vurgulandığı kavramsal bir yapıt olarak görülmektedir. Bu portre yapıtı bilinen biçimsel şekliyle değil, biyolojik verilere dayalı soyut bir görüntüdür ve bu soyut görüntü o kişiyi temsil etmektedir. Marc Quinn'in DNA portreleri, laboratuvar ortamında DNA klonlama yöntemi kullanılarak yapılmıştır. Sanatçı buna benzer portre çalışmalarında, fiziksel olarak her insanın birbirine benzediğini ama küçük bir oran yüzdesiyle insanların birbirinden ayrıldığını ifade etmekte ve bunu da her insanı diğer insanlardan ayıran bir özelliğinin olmasıyla açıklamaktadır (Yılmaz, 2018: 232233). DNA konusunu farklı teknik yönden ele alan başka bir sanatçı da Heather Dewey Hagborg' tur. Sanatçının yapmış olduğu 3D'li portre çalışmaları dikkat çekicidir (Görsel 2425).

Bu portrelerde Hagborg'un; sokaklardan toplamış olduğu sigara izmaritlerini, tırnak parçalarını, sakız ve saç gibi insanların genetik kanıtlarından analiz ederek; bu nesnelerden genetik kodlarını bularak o kişilerin gerçek ölçekte üç boyutlu modelini veya büstünü yaptığı görülmektedir. Sanatçının DNA portreleri, genellikle suçlu insanları veya kötü ün yapmış kişileri temsil etmektedir. Sanatçının 2012 ve 2013 tarihleri arasında yapmış olduğu "Tuhaf Görünüşler ( Stranger Visions )" adlı yapıt, suçluları veya kötü üne sahip insanların 

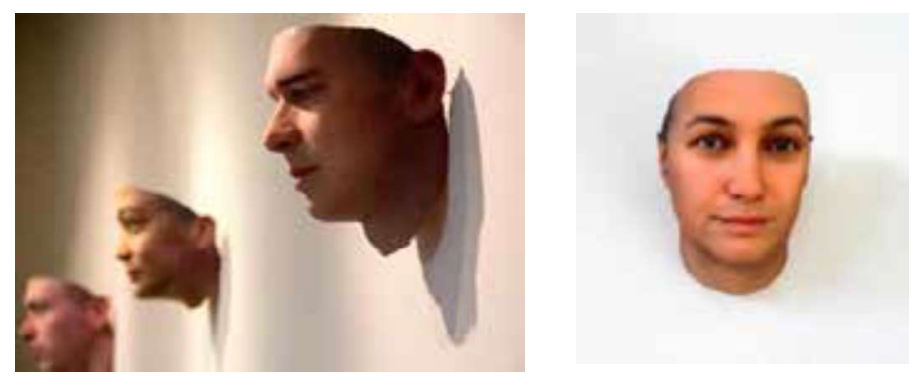

Görsel 24-25: Heather Dewey Hagborg, Portre ve New York'tan numuneler: Örnek 4, 1/6/13 12:20 Myrtle ave. And Himrod St. Brookly, NY MtDNA Haplogroup: T2b (Avrupali) SRY Geni: Yok Cinsiyet: Kadın rs12913832: AA Muhtemel Göz rengi: Kahverengi rs4648379:CT Biraz daha küçük burun boyutu rs6548238:TT Obezite için düşük oran

yüzlerini göstermektedir. Yapılan bu çalışma proje kapsamında ele alınmış ve neticesinde kamusal alana taşınmıştır. Kamusal alanda gerçekleştirilmiş olan bu çalışma ile suçlu insanların 3D baskıları yoluyla kimliklerinin ifşa edilmesi ve sınıflandırılması olasılığını gündeme getirmiştir. Sanatçının yapmış olduğu DNA portreler çalışmalarından sonra özel bir şirket saç, göz, deri rengi, yüz morfolojisi, cinsiyet ve genetik ataları tanımlayan "snapshot" isimli bir yazılım geliştirmiş ve bu yazılımda hukuki uygulamalara hizmet vermeye başla-

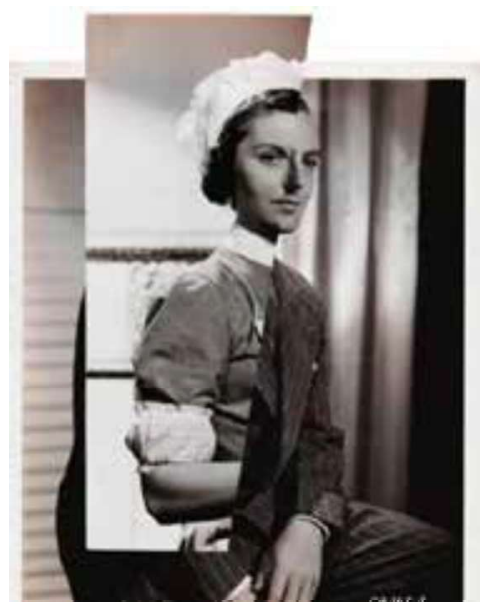

Görsel 26: John Stezaker, İhanet / Film Portreleri Serisi)

Kolaj Çalışması, 21,6 x 26,6 cm, 2007-08. mıştır (Yılmaz, 2018: 234-235).

Modern sanat akımları içerisinde kübizm ve dadaizm ile kullanılan kolaj tekniğinin postmodernizm içinde gelişimini sürdürdüğü görülmektedir. Günümüzde etkisini devam ettiren kolaj tekniği, farklı malzeme kullanımıyla çeşitlilik kazanmıştır. Günümüz sanatında kolaj tekniğini kullanan pek çok sanatçı bulunmaktadır. Bu sanatçılardan biri de John Stezaker'dir. Sanatçının yapmış olduğu çalışmaların, esrarengiz ve biraz rahatsız edici görsel imgelerden oluştuğu söylenebilir. Sanatçi; yapıtlarında eski kartpostalları, dergileri ve basılı argümanları kullanmıştır. $\mathrm{Bu}$ farklı malzeme kullanımına örnek olarak sanatçının yapmış olduğu "İhanet (Film Portreleri Kolajı)" isimli çalışma dikkat çekmektedir (Görsel 26). 


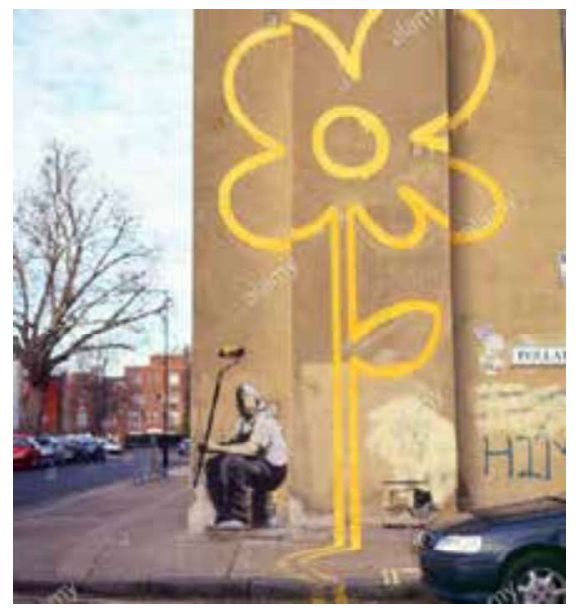

Görsel 27: Banksy, Sarı Çizgili Çiçe, 2008, Yaklaşık $250 \mathrm{~cm}$ Yüksekliğinde, Duvar Üzerine Graffiti Tekniği, Bethnal Green, Londra, İngiltere.
Daha önce ifade edildiği gibi postmodern sanat, farklı malzeme kullanımı çeşitli sanatsal tekniklerin ortaya çıkışını veya gelişimini sağlamıştır. Özellikle 1980'lerden itibaren bu gelişim açıkça fark edilmektedir. Bu gelişimi sürdüren sanat biçimi sokak sanatıdır. Sokak sanatının ilk oluşumuna bakıldığında grafiti tekniğiyle başladığı görülür. 1960'larda görülen bu grafiti tekniği, kamusal alanlara yazılan kalın harfli yazılar olarak ortaya çıkmıştır. Bu gelişim süreci içinde grafitinin; özellikle sprey boyanın kullanımıyla, çok renkli ve karmaşık kaligrafik tasvirlere dönüştüğü görülür. $\mathrm{Bu}$ tasvirler, toplu ulaşım araçlarına ve şehirlerin metrolarına çizilmişlerdir. Bu ilk grafiti çizimlerde popüler kültürden ve animasyon çizimlerinden yararlanıldığı dikkati çekmektedir. Grafiti tekniğiyle oluşan eserler, şehirlerin sosyal ve estetik kültürünü ortaya çıkarmıştır. Bu tekniğin zaman içinde önemini yitirmesiyle birlikte sanatçlarda alternatif yeni sanatsal biçimler ve yönelimler geliştirmeye çalışmışlardır. Bu yönelimler, sokak sanatının ortaya çıkmasını sağlamıştır (Farthing, 2012: 552-553) (Görsel 27).

Sokak sanatının bu kadar geniş kitlelere hitap etmesi, ilişkisel bir yapıda olmasıyla açıklanabilir. Çünkü bu ilişkisellik, galeri alanının dışına taşan (sınırlı bir alanda olmayan) geniş kitlelere yayılan ve toplumsal gündemin amaçlandığı bir merkez olarak görev yapmaktadır. Bu yeni form, birçok sanatsal biçimin birleşimiyle (Arazi, Grafiti, Resim, Fotoğraf vb.) oluşan melez bir yapı olarak görmek daha doğrudur (Witham, Pooke, 2013: 198). Yeni biçimle oluşan eserler, zamanımızın sanatsal görsel dili olarak var olmaktadır. Bu görsel dil teknolojik gelişmelerle birlikte günümüz sanatına yeni açılımlar ve farklı mekânsal boyutlar kazandırdığı anlaşılmaktadır.

Yeni teknolojik uygulama günümüz sanatı içinde dijital sanat olarak adını almıştır. Dijital sanatı, eserlerinde yansıtan pek çok sanatçı kullanmaya başladığı görülmektedir. Bu sanatçılardan biri de Harold Cohen'dir. Cohen, kendi tasarladığı bilgisayar programı sayesinde (AARON) sanatsal görüntüler oluşturmuştur. Sanatçının 1970'li yıllarda başladığı bilgisayar çizimlerini günümüze kadar ki süreç içinde geliştirdiği görülmektedir. Cohen, bilgisayar çizimlerinde ilk olarak siyah beyaz olarak baskılarını yapmış, daha sonra programın 
geliştirilmesiyle renkli baskılar yapılmaya başlanmıştır. Öncelikle bu çizimler basit şekillerden oluşmuştur. Daha sonra, programın yenilenmesiyle insan, bitki, obje ve iç mekân gibi suluboyayı andıran resimsel görüntüler elde edilmiştir (Görsel 28-29). Bu program sayesinde oluşturulan eserlerin yapay zekâ

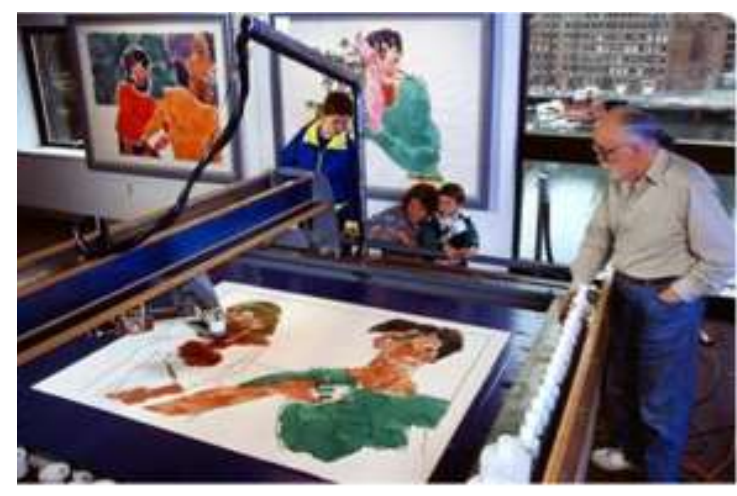

Görsel 28: Harold Cohen, Bilgisayar Çizimi Resim Yapımı, 1995, Bilgisayar Müzesi, Boston Amerika.

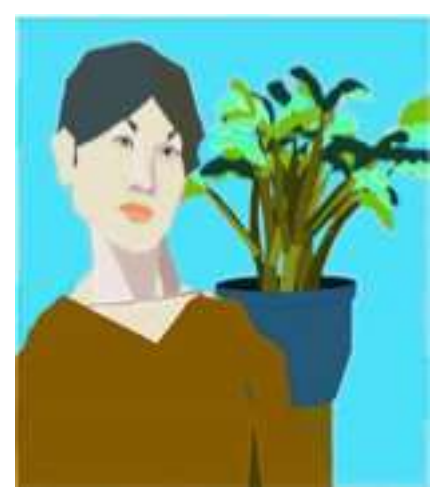

Görsel 29: Harold Cohen, AARON Tarafından Üretilen Resim, Plotter Bask1, Kağıt Üzerine Pigment Bilgisayar Görüntüsü, 2003 25 x $25 \mathrm{~cm}$, Courtesy Harold Cohen Arşivi.

ile sanatın yaratıcılığın tasarım boyutunun uyumlu birlikteliği göze çarpmaktadır. Sanatçının yapmış olduğu çalışmalarla bu noktaları iyi özümsediği ve bu yolla da yeni bir sanatsal bakış geliştirdiği görülmektedir (Tuğal, 2018: 163167).

Dijital çağ olarak adlandırılan 21. yüzyılda bilgi, hızlı ve etkili bir şekilde yaşamın her alanına nüfuz etmektedir. Bu yeni dönemin sanatçısı; sanatı, toplumu, doğayı, teknolojiyi kendi akıl süzgeci içinde tasarlamakta ve günümüz teknolojik uygulamalarla yapıtını oluşturmaktadır. Bunun yanında yapıtın estetik kriteri temsil anlayışından, bilgi üreten ve iletişim alanı yaratan bir eyleme dönüşmüştür. Sanatçılar; sonuçtan çok sürece odaklanmakta ve sanatı belirli bir sosyal grup için üretilmiş, meta değeri ile sınırlı nesne olmaktan çıkarıp, daha geniş bir sosyal bağlama işaret eden bir süreç olarak ele almaktadırlar. Günümüzde dijital sanat, fotoğraf, video, televizyon, bilgisayar, bask1, görüntü ve ses teknolojisinde yaşanan yeni gelişmelerin etkisiyle artık farklı disiplinlerin bir arada ve çok sayıda kombinasyonların kullanımı göze çarpmaktadır. Bu nedenle; tek kategoride ele alınamayan dijital sanat pratikleri, çeşitli uygulama alanları içinde barındıran melez mecralar adı altında ele alınmaya başlanmıştır. 
Öğr. Gör. Dr. AHMET UZUNER

Örneğin; dijital heykel, enstalasyon, sanal gerçeklik, performans-müzik-ses sanatı, veri tabanı, yazılım, oyun sanatı gibi kategoriler melez (hybrit) yaklaşımlar olarak öne çıkmaktadır (Yücel, 2012: 29, 32, 37).

\section{Sonuç}

Portre konusu, ilkel dönemlerden Rönesans'a kadar toplumsal, sosyolojik, politik ve dinî değişimlere paralel olarak gelişim göstermiştir. Rönesans'tan itibaren gelişen bilimsel, teknolojik ve düşünsel boyut sanatçılara yeni kapılar aralamaya başlamıştır. Aydınlanma çağı olarak adlandırılan Rönesans dönemi, sanatçılara özgür bir ortam yaratmıştır. Bu ortam içinde sanatçılar, portre yapıtlarını günlük yaşamın içinde yer alan insan yüzlerinden oluşturmaya başlamışlardır. Bu dönemde portre konusu çok sık işlenmiş ve bunun neticesinde sanatçıya iyi bir geçim kaynağı oluşturmuştur. Günümüze gelindiğinde ise portre, kavramsal bir boyut kazanarak öznenin bir temsili olarak öne çıkmıştır. $\mathrm{Bu}$ temsil ise, sanatçıya farklı sanatsal arayışlara doğru gidişi sağlamıştır. Sanattaki sunum şekilleri değişmiştir. Sanatçllar istedikleri her şeyi sanat nesnesi olarak kullanmaya başlamışlardır. Günümüz sanatında olan bu değişikliklerin temelinde bilimsel-düşünsel ilerlemenin büyük bir payı olduğu düşünülmektedir. Bu ilerleme insana, Rönesans'tan hatta İlk Çağ'dan beri devam eden bir şeyi merak etme olgusu olarak gelişim göstermiştir. İnsanoğlu tarafından geliştirilen bilimsel çalışmalar uzayın keşfi gibi farklı mekân-boyut keşfedilmiş ve keşfedilen bu yenilikler, sosyal yaşam içine taşınmaya başlanmıştır. Sanatçılarda, yaşanan bu yeni gelişmeleri eserlerine yansıtma çabası içine girmişlerdir. Sanatçıların eserlerini, günümüz sanatı olarak adlandırılan postmodernizmin temel özelliklerine göre şekillendirdikleri gözlenmiştir. Bu temel özellikler olan parodi, pastiş, ironi, melezleşme, küreselleşme, eklektizm, parçalanma, yapısöküm ve kültür gibi kavramlar, sanata ve sanatın konularına (natürmort, peysaj, figür, portre vb.) farklı biçimlerde veya anlamlarda yansıma olanağı bulmuştur. Portrenin plastik sanatların birbiri ile geçirdikleri etkileşimin yanı sıra başka alanların (felsefe, sosyoloji, psikoloji, antropoloji, bilim, teknoloji vb.) etkisiyle sanat çok anlamlı - biçimli bir yapıya dönüşmüştür. Portre konusunun da sanattaki bu oluşuma paralel gelişim gösterdiği anlaşılmıştır. Portrelerde konular psikolojik, sosyolojik, kültürel, teknolojik ve bilimsel yönden ele alındığı görülmüsstür. Portreler ağlayan, gülen, kızgın ve üzgün gibi duygu şekilleri psikolojik yönünü; işçi hareketleri, şiddet, kaza ölümleri belirten eleştirel yaklaşımlar sosyolojik yönünü; farklı kültürlere ait semboller kültürel yönüne; bilgisayar programlarıla yapılan (hologramlar, yapay zeka ile yapılmış çizimler, 3D...gibi) portreler teknolojik yönüne; uzayın keşfi, farklı mekânsal boyutlar ve genetik buluşlar portrelerin bilimsel yönüne vurgu yapmaktadır. Bunun sonucunda elde edilen portreler izleyen kişiye çok anlamlı ve 
katmanlı okuma olanağı sağlamıştır. Portrelerin, özellikle sanat tarihinde önemli yapıtların ele alınması, eskiden olduğu gibi bugün de devam ettiği ve geçmişi geleceğe taşıma rolünü üstlendiği gözlenmiştir.

\section{KAYNAKCA}

Alp Ö. Kafiye. (2013). Sanatın Temsili ve Post Modern Sanatta Temsil. Süleyman Demirel Üniversitesi Güzel Sanatlar Fakültesi Hakemli Dergi, 12, 58.

Altunay, D. Alper. (2013). Sanatın Ortamında Video, (1. Baskı). Eskişehir: Anadolu Üniversitesi Yayınları.

Brewer, J.D ve Teeter E (2011). Mısır ve Mısırlılar, (Çev. N. Uzan). Ankara: Arkadaş Yayınevi.

Carlson M. (2013). Performans Eleştirel Bir Giriş, (Çev. B. Güç Bilmez). Ankara: Dost Kitabevi.

Hodge, S. (2014). Gerçekten Bilmemiz Gereken 50 Sanat Fikri, (Çev. E. Gözgü). İstanbul: bk. Yayıncilik.

Farthing S. (2012). Sanatın Tüm Öyküsü. (Çev. G. Aldoğan, F. C. Çulcu). İstanbul: Hayalperest Yayınevi.

Şahiner R. (2015). Çağdaş Sanatta Temsiliyet Krizi, (1.Baskı). Ankara: Ütopya Yayınevi.

Şentürk V. L. Analitik Resim Çözümlemeleri, (1. Baskı). İstanbul: Ayrıntı Yayınları.

Thompson J. (2014). Modern Resim Nasil Okunur. (F. C. Çulcu). İstanbul: Hayalperest Yayınevi (Eserin orjinali 2006'da yayımlandı).

Tuğal, A.S. (2018). Oluşum Süreci İçinde Dijital Sanat, (1. Baskı), İstanbul: Hayalperest Yayınevi.

Turani, A. (1999). Dünya Sanat Tarihi, (10. Bask1). İstanbul: Remzi Kitabevi.

Uysal A. (2009). Yüzün Ötesi- Portre Kurmak Üzerine, Gazi Üniversitesi, Güzel Sanatlar Fakültesi, Sanat ve Tasarım Dergisi, l(4), 107-122.

Whitham G, Pooke G. (2013). Çağdaş Sanatı Anlamak. (Çev. T. Göbekçin). İstanbul: Optimist Yayıncilık.

Yılmaz O. (2015). Sanat Akımları Üzerinden Gelișen Disiplinlerarası Sanat, International Periodical for the languages, Literature, and History of Turkish, (10), 1003,1008

Y1lmaz,T.S. (2018).Çağdaş Sanatta Portre-Kimlik İlişkisi: DNA, Düzce Üniversitesi, Sanat, Tasarım ve Mimarlık Fakültesi, Akademik Sosyal Araştırmalar Dergisi, 6 (83), 227-237.

Yücel D. (2012). Yeni Medya Sanatı ve Yeni Müze, (1. Bask1). İstanbul: İstanbul Kültür Üniversitesi Yayın No; 166.

\section{GÖRSEL KAYNAKLAR}

Görsel 1. https://www.deseret.com/2006/6/4/19956863/ancient-skeleton-art-found-infrench-cave( Erișim Tarihi:08.07.2020).

Görsel 2. http://archaic.totalarch.com/pyramids_and_mastabas_michalowski_dziewanowski( Erişim Tarihi:08.07.2020).

Görsel 3. https://www.history.org.uk/primary/resource/8683/teaching-the-ancient-greeks(Eri "https://www.history.org.uk/primary/resource/8683/teaching-the-ancient-greeks(Erişim"şim Tarihi:08.07.2020)

Görsel 4. https://arkeofili.com/pompeiinin-freskleri-antibiyotikle-temizlendi/(Eri "https://arkeofili.com/pompeiinin-freskleri-antibiyotikle-temizlendi/(Erişim"şim Tarihi:08.07.2020)

Görsel 5. https://upload.wikimedia.org/wikipedia/commons/2/2b/Detail_of_Koimesis_Mosaic_at_ 
Öğr. Gör. Dr. AHMET UZUNER

Chora_Church.jpg ( Erişim Tarihi:08.07.2020)

Görse-16.http://www.uffizi.it/en/online-exhibitions/between -human-and-divine-cimabueand-the-santa-trinita-maesta ( Erişim Tarihi:08.07.2020)

Görsel7.https://yandex.com.tr/gorsel/search?p=8\&text=Aziz\%20Daniel\%2C\%20vitray $\% 20$ tekni $\%$ C4\% 9 Fi\&pos $=264 \&$ rpt $=$ si-

mage\&img_url=https\%3A\%2F\%2Fwww.wga.hu\%2Fart\%2Fzgothic\%2Fstai-

ned\%2F 12c\%2F 1\%2F00g_1100.jpg\&from=tabbar ( Erişim Tarihi: 08.07.2020 )

Görsel 8. http://www.medievalart.org.uk/Chartres/030a_pages/Chartres_Bay030a_Panel20.htm( Erişim Tarihi:09.07.2020 )

Görsel 9.https://yandex.com.tr/search/?text=gi-

otto\%20dante\&lr=103888\&clid=21866171622.jpg ( Erişim Tarihi:09.07.2020 )

Görsel 10. https://tr.wikipedia.org/wiki/Dosya:Van_Eyck_-_Arnolfini_Portrait.jpg ( Erişim Tarihi: 10.07.2020)

Görsel 11. https://www.hoocher.com/El_Greco/El_Greco.htm ( Erişim Adresi: 10.07.2020 )

Görsel12.https://yandex.com.tr/gorsel/search?from=tabbar\&text=arcimboldo $\& \mathrm{p}=4 \&$ pos $=122 \& \mathrm{rpt}=$ simage \&img_url $=\mathrm{https} \% 3 \mathrm{~A} \% 2 \mathrm{~F} \% 2 \mathrm{Fwww} \cdot \operatorname{maximitalia} . \mathrm{it} \% 2 \mathrm{Fwp}$ content\%2Fuploads\%2F2018\%2F11\%2Fvan-dyck-e1542198512244.jpg ( Erişim Tarihi: 10.07.2020)

Görsel13.https://www.rijksmuseum.nl/en/search/objects?q=slave+rembrandt

"'https://www.rijksmuseum.nl/en/search/objects?q=slave+rembrandt\&p=3\&ps="ps=12\&st

$=$ Objects\&ii=7\#/RP-P-OB-410,31( Erişim Tarihi: 10.07.2020)

Görsel 14. https://www.louvre.fr/en/oeuvre-notices/pierrot-formerly-known-gilles ( Erişim Tarihi: 10.07 .2020 )

Görsel 15. https://domainedechantilly.com/en/accueil/chateau/the-art-galleries/selectedworks/ ( Erişim Tarihi:10.07.2020)

Görsel16.https://useum.org/artwork/Self-portrait-with-Dr-Arrieta-Francisco-de-Goya-1820 ( 10.07.2020)

Görsel17.https://yandex.com.tr/gorsel/search?text=gustave $\% 20$ courbet $\% 20$ self $\% 20$ portrait\&from=tabbar\&pos=4\&img_url=https $\% 3 \mathrm{~A} \% 2 \mathrm{~F} \% 2 \mathrm{~F}$ arthistoryproject.com $\% 2 \mathrm{Fsite} \% 2 \mathrm{Fas}-$ sets\%2Ffiles\%2F10671\%2Fgustav_courbet_-_the_desperate_man_1844-

$45 \_45 \times 55 \mathrm{~cm} \_$pc.jpg\&rpt $=$simage (Erişim Tarihi:

10.07.2020)

Görsel 18. https://www.artic.edu/artworks/14655/two-sisters-on-the-terrace (Erişim Tarihi: 10.07.2020)

Görsel 19. https://i.pinimg.com/origi-

nals/fd/53/1d/fd531d64a08e3a3290d69049076d91d1.jpg ( Erişim Tarihi: 10.07.2020 )

Görsel 20. https://static1.museoreinasofia.es/sites/default/files/obras/AD05280_0.jpg ( Erişim Tarihi:

10.07.2020)

Görsel 21. http://o-glavnom.rosizo.ru/wp-content/uploads/2018/09/1-lec.-joseph-beuyshow-to-explain-pictures-to-a-dead-hare-1965.jpg ( Erişim Tarihi: 10.07.2020 )

Görsel 22. https://i.ytimg.com/vi/zjoEzDv5rPs/hqdefault.jpg ( Erişim Tarihi: 10.07.2020 )

Görsel23.https://yandex.com.tr/search/?text=.\%20Marc\%20Quinn\%2C\%20A\%20Genomic\%20Portrait\%3ASir\%20John\%20Sulston\&lr=103888\&clid=2186617 ( Erișim Tarihi: 10.07.2020)

Görsel 24-25. https:// "https://deweyhagborg.com/projects/stranger-visions"deweyhagborg.com/projects/stranger-visions ( Erişim Tarihi: 10.07.2020 ) 
AKRA KÜLTÜR SANAT VE EDEBIYAT DERGİSİ 2021 (S.24) c.9 / s.93-115

Görsel 26. https://i.pinimg.com/origi-

nals/84/54/bd/8454bd972f2292b9d417b288ddbe92e0.jpg ( Erişim Adresi: 10.07.2020 )

Görsel 27. https://c8.alamy.com/comp/ANA8XP/banksy-yellow-line-flower-painting-andpainter-with-a-roller-on-a-ANA8XP.jpg ( Erişim Adresi: 11.07.2020 )

Görsel28.https://yandex.com.tr/gorsel/search?text=harold\%20 cohen $\% 20$ aaron\&from=tabbar\&pos=0\&img_url=https $\% 3 \mathrm{~A} \% 2 \mathrm{~F} \% 2 \mathrm{Fcdn} 2$.techbang.com $\% 2$ Fsystem $\% 2 \mathrm{Fima}$ ges $\% 2 \mathrm{~F} 455090 \% 2$ Forigi-

nal\%2Fd54d5202ad425198af41eca48605570d.jpg\%3F1534479380\&rpt=simage (Erişim Adresi:11.07.2020)

Görsel 29. https://www.studiointernational.com/index.php/delving-into-coding-the-art-ofharold-cohen-aaron-computer-generated ( Erişim Adresi: 11.07.2020) 